\title{
Economic and Environmental Evaluations of Extractable Coal Resources Conducted by the U.S. Geological Survey
}

\section{Introduction}

The Economic and Environmental Evaluations of Extractable Coal Resources (E4CR) project integrates economic analyses of extractable coal resources with environmental and coal quality considerations in order to better understand the contribution that coal resources can make to help meet the Nation's future energy needs. The project utilizes coal resource information derived from the recent National Coal Resource Assessment (NCRA), National Oil and Gas Assessment (NOGA), and Coal Availability and Recoverability Studies (CARS) conducted by the U.S. Geological Survey and other State and Federal cooperating agencies. The E4CR evaluations are designed to augment economic models created by the U.S. Geological Survey CARS and NCRA projects and by the Department of Energy/Energy Information Administration (DOE/EIA).

E4CR evaluations are conducted on potentially minable coal beds within selected coalfields in the United States. Emphasis is placed on coalfields containing Federally owned coal and within or adjacent to Federal lands, as shown in U.S. Geological Survey Fact Sheets 012-98, 145-99, and 011-00 (U.S. Geological Survey, 1998, 1999, 2000). Other considerations for the selection of study areas include coal quality, potential environmental impact of coal production activities and coal utilization, the potential for coalbed methane development from the coal, and projected potential for future mining. Completion dates for the E4CR studies loosely follow the schedule for analogous NOGA studies to allow for a comparison of different energy resources in similar geographic areas.

\section{Restrictions to Mining}

The United States has a large supply of in-place coal resources. However, a variety of factors limit the amount of coal resources that can be produced and utilized. Federal land-use restrictions, such as the designation of certain lands as wildlife refuges, wetlands, and national parks or monuments can limit what Federal lands can be developed. Some of these land-use restrictions are related to areas of environmental concern, such as the protection of wildlife habitat, water supply and quality issues, and air quality issues. Areas defined as alluvial valley floors, in many cases, would not be developed because of a possible detrimental effect on water supply and water quality.

Surface and underground coal mining operations may not be compatible with infrastructure such as towns, roads, and power lines. These societal factors must be considered in a determination of what areas can be mined. In the case of most towns, either the specific area must be avoided entirely or the area to be mined is selected to exclude the area of the feature plus a buffer area around it. In the case of many county and State roads, a road can be relocated, detouring it around the area to be mined; and if necessary, after mining and reclamation are completed, the road can be rebuilt in its original location.

Other limits to coal mining are primarily economic in nature. Geologic factors can be unfavorable to mining. The type and thickness of rock above and between the coal beds, the coal thickness, the dip of the coal beds, the existence of aquifers, the presence of clinker (burned coal and adjacent cooked rock), and faulting in the mine area

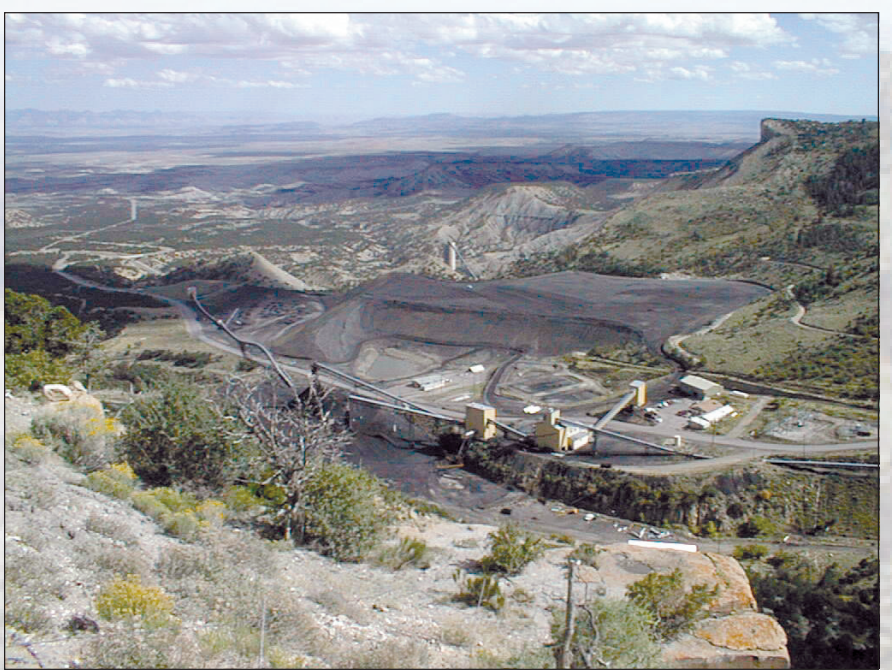

Underground mine in the northern Wasatch Plateau, central Utah.

can cause problems that may make the cost of mining prohibitive. Such factors can vary from one area to the next. This variability from coalfield to coalfield can necessitate the use of different equipment and methods to extract, process, store, and transport coal, which can limit the amount of coal that can be mined at a reasonable profit.

In addition, some coal beds might not be mined because their high sulfur content would necessitate costly cleaning to meet maximum allowable $\mathrm{SO}_{2}$ emissions standards. Standards have been set by the Environmental Protection Agency specifying the amount of $\mathrm{SO}_{2}$ emissions that are allowed from coal-fired power plants. The $\mathrm{SO}_{2}$ emissions relate directly to the sulfur content and the BTU (heat) value of the coal, and are measured in pounds of $\mathrm{SO}_{2}$ per million BTU. Highsulfur coal can be cleaned prior to power plant utilization, and $\mathrm{SO}_{2}$ emissions can be reduced through the use of flue gas scrubbers, but cleaning adds to the cost of producing electricity. Non-compliant coal is less likely to be developed, because it must be cleaned or blended with higher quality coal to meet individual contract specifications or emissions standards.

\section{Methodology for Calculating Coal Resources}

The U.S. Geological Survey and workers in cooperating State agencies have developed a method for determining the quantity of coal that may be economically recoverable under current and foreseeable conditions. This method was developed as part of the Coal Availability and Recoverability Studies (CARS) project and refined by the E4CR project. The following is a brief description of the project method.

1. A detailed study is made of the geology and stratigraphy of coal beds of interest and related rock units in a given area. Coal beds are correlated and the original coal resource is calculated.

2. Areas that have already been mined are removed from the original coal resource area. The amount of coal in the remaining area is the remaining coal resource. 
3. Areas where mining cannot take place because of Federal or State land-use restrictions are removed from the remaining resource area. The area that is left contains the coal that is available for development, or the available coal resource.

4. The amount of coal that cannot be recovered because of mining and washing losses is subtracted from the available coal resource leaving the recoverable coal resource.

5. Economic analysis is applied to the coal that is recoverable to calculate how much of the coal can be mined at a profit in the current coal market and how much can be profitably mined if the market changes (economic cost curve). Economic considerations are determined by the location of the mine, availability and type of transportation for the coal, mining methods and equipment, coal and surrounding rock characteristics, and coal quality. Coal that is not considered to be economic for production is subtracted from the recoverable resource leaving the economic resource or the reserve.

The histogram shows the differences between coal resources in several large E4CR study areas after restrictions have been applied to the original calculated coal resources. Some of the most striking differences in the amount of economic resources result from the availability of transportation and distance from the coalfield to the consumer (in most cases a coal-fired power plant). Studies indicate that some coal from the Bisti coalfield could be profitably mined for use at a mine-mouth power plant. Detailed descriptions of CARS studies appear in reports by Carter and others (1989); Eggleston and others (1990); Rohrbacher and others (1993); Rohrbacher, Teeters, Osmonson, and Plis (1994); Rohrbacher, Teeters, Sullivan, and Osmonson (1994); Molnia and others (1997); Molnia and others (1999); Scott (1995); and Osmonson and others (2000).

\section{Conclusion}

The E4CR project uses a slightly modified version of the methodology developed by the CARS project to determine the amount of original, available, recoverable, and economic coal resources in each study area. The E4CR project defines larger study areas, recalculates the original coal resource to include partings, and applies more restrictions to coal resources than in past studies. In addition to the calculation of coal resources for specific minable beds in each study area, the E4CR project also addresses areas of potential conflict that could restrict the development of coal resources. Some of these include mixed land use, hydrologic and water quality considerations, and the development of several different energy resources within the same area. The E4CR project provides a comprehensive analysis of coal resource development potential. The project does not provide a detailed mine plan, but it presents a reality-based assessment that can be used by Federal and State agencies, public officials, and those in the private sector to make significant and informed land-use and resource development decisions.

\section{References Cited}

Carter, M.D., and Gardner, N.K., 1989, An assessment of coal resources available for development, central Appalachian region: U.S. Geological Survey Open-File Report 89-362, 52 p.

Eggleston, J.R., Carter, M.D., and Cobb, J.C., 1990, Coal resources available for development-A methodology and pilot study: U.S. Geological Survey Circular 1055, $15 \mathrm{p}$.

Molnia, C.L., Biewick, L.R.H., Blake, Dorsey, Tewalt, S.J., Carter, M.D., and Gaskill, Charlie, 1997, Coal availability in the Hilight quadrangle, Powder River Basin, Wyoming - A prototype study in a western coal field: U.S. Geological Survey Open-File Report 97-469, 21 p.

Molnia, C.L., Osmonson, L.M., Wilde, Edith, Biewick, L.R.H., Rohrbacher, T.J., and Carter, M.D., 1999, Coal availability and recoverability studies in the Powder River Basin, Wyoming and Montana, Chapter PAR in Fort Union Coal Assessment Team, 1999, Resource assessment of selected Tertiary coal beds and zones in the Northern Rocky Mountains and Great Plains Region: U.S. Geological Survey Professional Paper 1625-A, 119 p.

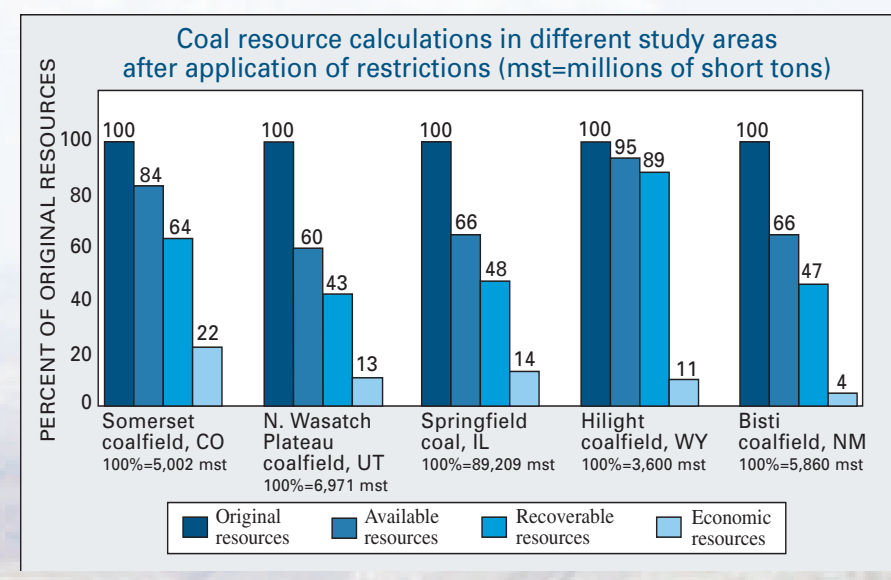

Osmonson, L.M., Rohrbacher, T.J., Molnia, C.L., and Sullivan, G.L., 2000, Coal recoverability in the Hilight quadrangle, Powder River Basin, Wyoming; a prototype study in a western coal field: U.S. Geological Survey Open-File Report 00-103, 23 p.

Rohrbacher, T.J., Teeters, D.D., Osmonson, L.M., and Plis, M.N., 1994, Coal recoverability and the definition of coal reserves, central Appalachian region, 1993: U.S. Bureau of Mines Open-File Report 10-94, 36 p.

Rohrbacher, T.J., Teeters, D.D., Sullivan, G.L., and Osmonson, L.M., 1993, Coal reserves of the Matewan quadrangle, Kentucky_A coal recoverability study: U.S. Bureau of Mines Information Circular 9355, 36 p.

Rohrbacher, T.J., Teeters, D.D., Sullivan, G.L., and Osmonson, L.M., 1994, Coal reserves of the Boltsfork quadrangle, Kentucky-A coal recoverability study: U.S. Bureau of Mines Information Circular 9379, 30 p.

Scott, D.C., 1995, Coal recoverability and coal reserve analysis, Illinois Basin, Western Kentucky coal field, 1995: U.S. Bureau of Mines Open-File Report 75-95, 21 p.

U.S. Geological Survey, 1998, Digital database of coal ownership: U.S. Geological Survey Fact Sheet FS-012-98.

U.S. Geological Survey, 1999, Federal coal in the Colorado Plateau Region: U.S. Geological Survey Fact Sheet FS-145-99, 4 p.

U.S. Geological Survey, 2000, Federal coal in the Northern Rocky Mountains and Great Plains Region: U.S. Geological Survey Fact Sheet FS-011-00, 6 p.

\section{For further information on the E4CR project, contact:}

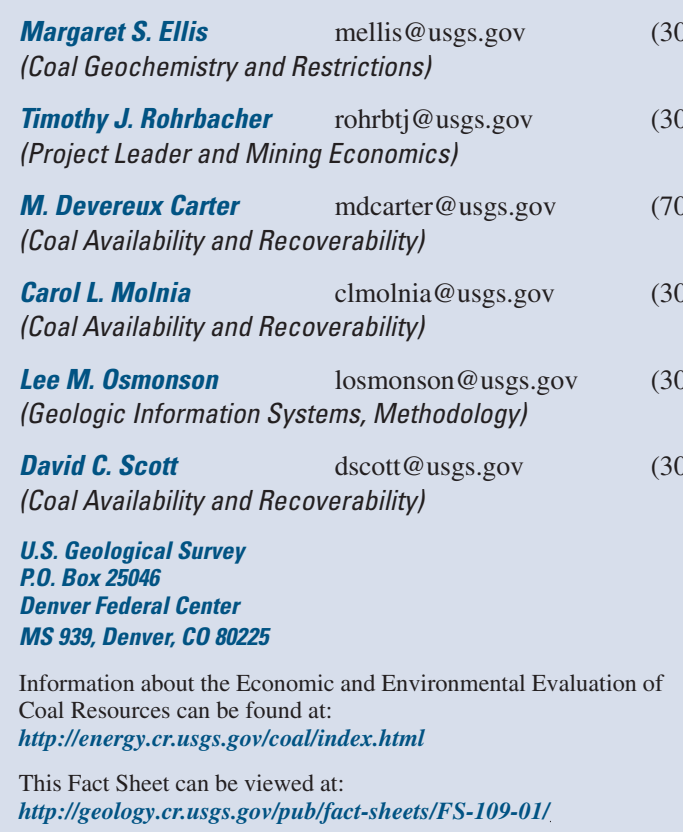

(303) 236-7775

(303) 236-3614

(703) 648-6413

(303) $236-7769$

(303) $236-3613$

(303) 236-3616

$$
\text { U.S. Geological Survey Professional Paper 1625-A, } 119 \text { p. }
$$

